\section{Household Detergent on Tomato: Phytotoxicity and Toxicity to Silverleaf Whitefly}

\author{
C.S. Vavrina, P.A. Stansly, and T.X. Liu \\ University of Florida, Southwest Florida Research and Education Center, \\ P.O. Drawer 5127, Immokalee, FL 33934
}

Additional index words. soap, delayed maturity, whitefly

\begin{abstract}
Household detergents were evaluated in field studies on fresh-market tomato (Lycopersicon esculentum Mill.) for insecticidal and phytotoxic effects. Laboratory bioassays were used to examine the toxicity of a household liquid dish detergent on small nymphs of silverleaf whitefly, Bemisia argentifolii Bellows and Perring. The detergents tested proved to be more toxic to whitefly nymphs than the commercial insecticidal soap. Detergent treatments were applied to tomato with a commercial high pressure hydraulic sprayer at $0 \%, 1 \%, 2 \%, 4 \%$, and $8 \%$ (by volume) initially and at $0 \%, 0.25 \%, 0.5 \%, 1.0 \%$, and $2.0 \%$ (by volume) in subsequent tests. As detergent rate, frequency of application, or both increased, plant dry weight accumulation and fruit yield decreased. Applying detergent also increased time to fruit maturity. A once-a-week application of $0.25 \%$ to $0.5 \%$ detergent initially applied 2 weeks after transplanting alleviated phytotoxicity and yield reduction problems.
\end{abstract}

Soap was the first man-made detergent (Kirk, 1983) and has been used as an insecticide to control soft-bodied insects for many years (Puritch, 1975). Interest in using nonsoap detergents as insecticides has grown as their application in large-scale commercial agriculture has increased (Vavrina, 1992). Expanded usage is due to a perceived efficacy among growers and an economic advantage over conventional insecticides. To date, little information exists on the insecticidal or phytotoxic effects of nonsoap detergents. Commercially available insecticidal soap [e.g., M-Pede (Mycogen, San Diego)] is generally more expensive than nonsoap detergents and less soluble in hard water. Yepsen (1984) recommended a $1 \%$ soap solution for the control of soft-bodied insects on organically grown vegetables. In efficacy studies on silverleaf whitefly (SLWF) Bemisia argentifolii (formerly the sweetpotato whitefly B. tabaci Gennadius), nonsoap detergents provided effective control at $0.25 \%$ to $1 \%$ (Butler and Henneberry, 1990; Butler et al., 1993; Stansly and Liu, 1994). However, Vavrina (1992) found a $1 \%$ nonsoap detergent to be phytotoxic to tomato when using commercial pressures and volumes in repeated applications in the field.

Our purpose was to determine the rate and frequency of application of nonsoap detergent that would be nonphytotoxic to tomato under field conditions and evaluate the efficacy of a

Received for publication 31 Jan. 1995. Accepted for publication 23 June 1995. Florida Agricultural Expt. Station Journal Series no. R-03833. The use of brand names does not constitute a recommendation by the Univ. of Florida to the exclusion of other products. The cost of publishing this paper was defrayed in part by the payment of page charges. Under postal regulations, this paper therefore must be hereby marked advertisement solely to indicate this fact. nonsoap in controlling SLWF under laboratory bioassay conditions.

\section{Materials and Methods}

Four field studies were conducted to determine phytoxicity of household detergents on 'Sunny' tomato: one detergent rate screening trial on young transplants and three field studies taken to harvest. Meteorological data were recorded during all trials.

Nonsoap detergent insecticidal bioassay. The B. argentifolii (source: David Schuster, Univ. of Florida, Gulf Coast Research and Education Center, Bradenton) used in this study was identified as B. tabaci 'Biotype B' in 1992 (T.M. Perring, Univ. of California at Riverside, personal communication) and as $B$. argentifolii in 1994 (A.C. Bartlett, U.S. Dept. of Agriculture, Agricultural Research Service, Phoenix; personal communication). The colony was maintained in an established greenhouse culture on potted tomato plants ('Lanai') grown in Metro-Mix 300 soilless medium (Grace Sierra Horticultural Products Co., Milpitas, Calif.) and fertilized with $12 \mathrm{~N}-8 \mathrm{P}-$ $6 \mathrm{~K}$ slow-release fertilizer.

Whitefly-free tomato plants were placed in a greenhouse with a whitefly colony and infested with adults by agitating adjacent plants. After a 24-h oviposition period, the newly infested plants were removed from the colony and cleaned of adults using a hand-held vacuum cleaner (AC Insect Vac; BioQuip, Gardena, Calif.). The egg-bearing leaves were incubated in whitefly-free cages at $25 \pm 2 \mathrm{C}, 75 \%$ relative humidity $(\mathrm{RH})$, and a $14-\mathrm{h}$ light : $10-\mathrm{h}$ dark period for 7 days when most were first instars.

Two materials were assayed in separate studies. M-Pede is an insecticidal soap [potassium salt (49\%) of a naturally derived fatty acid]. New Day is a dish-washing liquid with a $\mathrm{pH}$ of 8.3 , a dry weight of $38.3 \%$, and the following active ingredients (26\%): sodium dodecyl benzene sulphonate and sodium laurylether sulphate (Peck's Products Co., St. Louis). The concentrations tested were M-Pede at $0 \%, 0.2 \%, 0.5 \%, 1.0 \%, 2.0 \%, 3.0 \%, 4.0 \%$, $6.0 \%$, and $8.0 \%(\mathrm{v} / \mathrm{v})$ and New Day at $0 \%$, $0.2 \%, 0.5 \%, 1.0 \%, 2.0 \%$, and $3.0 \%(\mathrm{v} / \mathrm{v})$.

All experiments were conducted in a laboratory, and all treated leaves then were kept in an insectary at $25 \pm 2 \mathrm{C}$ and $70 \% \pm 5 \% \mathrm{RH}$ and illuminated with fluorescent lights at a photoperiod of $14 \mathrm{~h}$ light : $10 \mathrm{~h}$ dark. Infested tomato leaves (trifoliates) were dipped for $5 \mathrm{sec}$ in the appropriate solutions, air-dried for $2 \mathrm{~h}$, and placed individually into glass vials (petiole down) provided with $20 \mathrm{ml}$ of water. A vial was secured in the center of a cup cage. The treated leaf was incubated for 4 days and later examined using a dissecting microscope. An average of $54(\mathrm{SD}=14)$ nymphs per leaf were examined. Mortality calculations were based on the number of nymphs that had either dehydrated or were detached from the leaf surfaces. Each treatment consisted of eight leaves, and the experiment was repeated three times. The lethal concentration of a material needed to kill $50 \%\left(\mathrm{LC}_{50}\right)$ or $90 \%\left(\mathrm{LC}_{90}\right)$ of nymphs exposed, as well as $95 \%$ confidence limits around these values, were computed using a probit procedure (PROC PROBIT LOG10; SAS Institute, 1988).

Field rate screening (Summer 1991). Application rates were screened to assess phytotoxicity during summer conditions and to determine detergent concentration ranges for subsequent trials. We used Tide liquid (Proctor \& Gamble, Cincinnati) at $0 \%$ (water control), $1 \%, 2 \%, 4 \%$, and $8 \%(\mathrm{v} / \mathrm{v})$. Tide liquid (dry weight $37 \%$ and a $\mathrm{pH}$ of 8.3 ) included the same anionic surfactants as New Day (principal active ingredients $=$ anionic surfactants sodium dodecyl benzene sulphonate and sodium laurylether sulphate).

Polyethylene-mulched beds, which had previously been used for a spring tomato crop, were injected with $5.5 \mathrm{~kg}$ of $\mathrm{N}$ and $\mathrm{K} / \mathrm{ha}$ as a $\mathrm{KNO}_{3}$ liquid fertilizer. Tomatoes were transplanted $0.5 \mathrm{~m}$ apart on 20 June at 12 plants per plot. Treatments were arranged in a randomized complete-block design with four replications. Spray treatments of detergent were made at $\approx 11: 00$ AM with a backpack $\mathrm{CO}_{2}$-powered sprayer calibrated to deliver 468 liters $\cdot \mathrm{ha}^{-1}$ at $276 \mathrm{kPa}$. Spraying began 1 week after planting and continued twice weekly for 3 weeks. Phytotoxicity ratings were taken $24 \mathrm{~h}$ after each treatment application by visual assessment of the percentage of injured foliage. After terminating treatments, the above-ground portions of five plants per plot were harvested and dried 7 days at $70 \mathrm{C}$. The dried plant material was allowed to reach room temperature in a desiccator and then was weighed.

Field studies (general). All field studies were conducted on Immokalee fine sand (sandy, silicaceous, hyperthermic, Arenic Haplaquods) under subsurface seepage irrigation. Each crop received $224 \mathrm{~kg}$ N/ha, $291 \mathrm{~kg}$ $\mathrm{K} / \mathrm{ha}$, and $\mathrm{P}$ as determined by soil test (56 $\mathrm{kg} \cdot \mathrm{ha}^{-1}$ in Fall, $78 \mathrm{~kg} \cdot \mathrm{ha}^{-1}$ in Spring). The N 
and $\mathrm{K}\left(67 \mathrm{~kg} \cdot \mathrm{ha}^{-1}\right)$ and all the P plus micronutrients were broadcast and then bedded over to a depth of 13 to $15 \mathrm{~cm}$. The remaining $\mathrm{N}$ and $\mathrm{K}$ were applied in two narrow bands on top of the bed, $17 \mathrm{~cm}$ to either side of the center. The field was fumigated simultaneously with 314 $\mathrm{kg} 98 \%$ methyl bromide (2\% chloropicrin)/ha, and the final bed was shaped. The beds then were covered with $0.04-\mathrm{mm}$-thick polyethylene mulch (black in spring, white-on-black in fall). The beds were $90-\mathrm{cm}$-wide, single rows on $1.8-\mathrm{m}$ centers.

Tomatoes were transplanted $0.5 \mathrm{~m}$ apart in plots $12.2 \mathrm{~m}$ long in a randomized completeblock design with four replications in Fall 1991 and Spring 1992 and six replications in Fall 1992. Spray applications to the plots were made with a trailer-mounted, commercial highpressure hydraulic sprayer (diaphragm pump) equipped with two drop lines, each fitted with a maximum of six ceramic hollow cone tips (Albuz ATR Red delivering $\approx 1.6$ liters $\cdot \mathrm{min}^{-1}$ at $887 \mathrm{kPa}$ ) calibrated at 580 to 784 liters $\cdot \mathrm{ha}^{-1}$ or 572 to 878 liters.ha ${ }^{-1}$. To ensure continued coverage as plant height increased, spray volumes were increased by adding nozzles.

Based on the results of the screening trial, detergent concentrations were reduced to $\leq 2 \%$ in the field trials. Phytotoxicity often was not visible in these trials; thus, decreases in plant dry weight and yield were used as a sign of phytotoxicity.

Shoot dry weight biomass was determined for one randomly chosen plant per plot at 2week intervals after planting for 2 to 8 weeks in Fall 1991 and 2 to 10 weeks in Spring 1992. Harvested fruit were separated into red and green categories by medium, large, and extralarge size classifications according to specifications defined by the Florida Tomato Exchange (Hawkins, 1994). Assessments of plant dry weight (Fall 1991 only), early and total marketable fruit weight, and mean fruit weight were analyzed by regression analysis for Fall 1991 and analysis of variance, with mean separation using Fisher's least significant difference, for Spring 1992 and Fall 1992 (SAS Institute, 1988).

Fall 1991. Transplants were set 9 Sept. New Day liquid detergent at five concentrations $[0 \%, 0.25 \%, 0.5 \%, 1 \%$, and $2 \%(\mathrm{v} / \mathrm{v})]$ was applied foliarly either once or twice a week, beginning 1 week after planting and continuing for 12 weeks. Fruit were harvested on 19 Dec. 1991 and 3 and 13 Jan. 1992.

Spring 1992. Tomatoes were transplanted

Table 1. Dosage response for first instar nymphs of silver leaf whitefly (Bemesia argentifolii) to New Day liquid detergent and M-Pede insecticidal soap.

\begin{tabular}{lcc}
\hline Criterion $^{z}$ & New Day & M-Pede $^{y}$ \\
\hline $\mathrm{LC}_{50}(\%)$ & 0.076 & 0.149 \\
95\% CL LC & 0.055 to 0.096 & 0.110 to 0.197 \\
$\mathrm{LC}_{90}(\%)$ & 0.522 & 0.836 \\
$95 \% \mathrm{CL} \mathrm{LC}$ & 0.402 to 0.752 & 0.577 to 1.400 \\
Slope $\pm \mathrm{SE}$ & $1.49 \pm 0.28$ & $1.71 \pm 0.15$ \\
\hline
\end{tabular}

${ }^{2} \mathrm{LC}_{50}=$ lethal concentration for $50 \%$ of population; $\mathrm{CL}=$ confidence limits; $\mathrm{LC}_{90}=$ lethal concentration for $90 \%$ of population.

${ }^{y}$ Data cited were from separate studies. on 3 Mar. Based on results of the Fall 1991 study, three New Day concentrations $[0 \%$, $0.25 \%$, and $0.5 \%(\mathrm{v} / \mathrm{v})]$ were sprayed once or twice a week beginning 1 week after planting and continuing for 12 weeks. Fruit were harvested on 5 May and 1 June.

Fall 1992. Seedlings were transplanted on 29 Sept. The first detergent treatments were

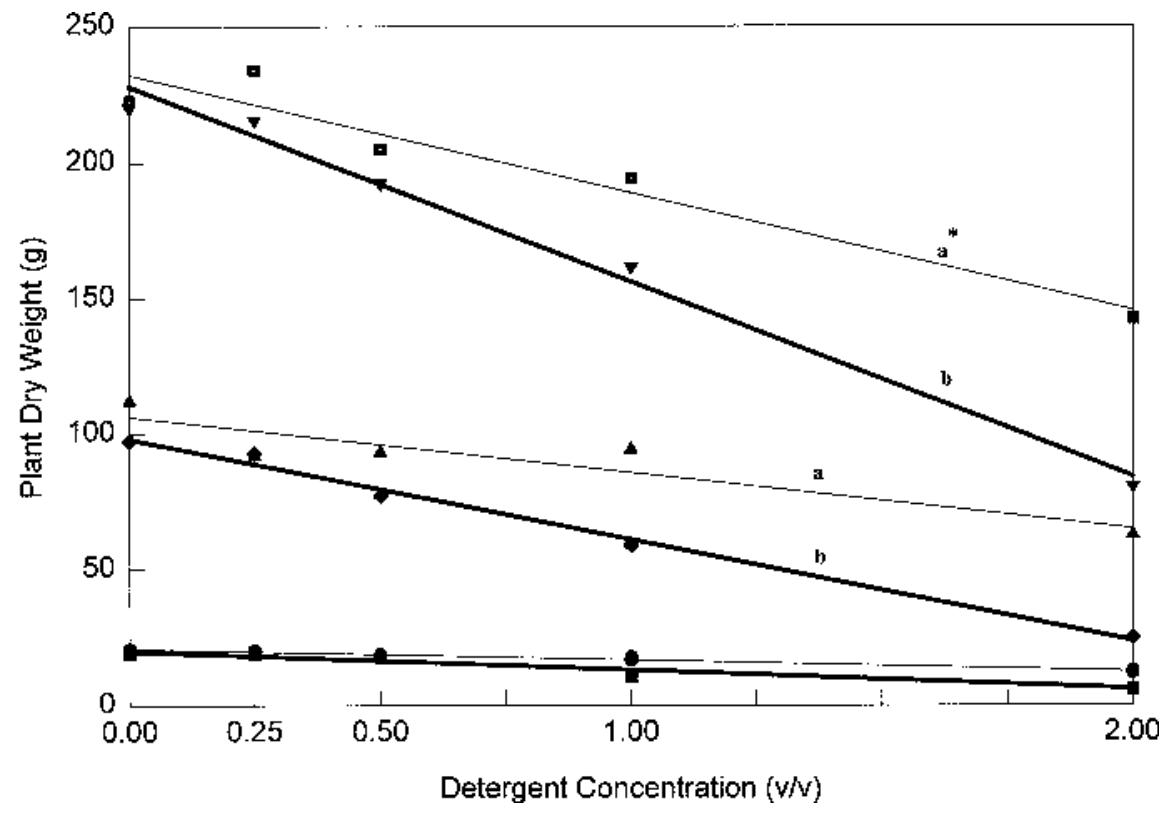

Fig. 1. The effect of New Day liquid detergent application frequency on 'Sunny' tomato shoot dry weight for $\leq 8$ weeks after transplanting, Fall 1991. (-) y $=-4.10(x)+20.7, r^{2}=0.24$, once per week, week 4; (四) $\mathrm{y}=-6.52(\mathrm{x})+19.7, r^{2}=0.50$, twice per week, week $4 ;(\boldsymbol{\Lambda}) \mathrm{y}=-20.7(\mathrm{x})+106.3, r^{2}=0.34$, once per week, week 6; $(\bullet) \mathrm{y}=-37.1(\mathrm{x})+98.0, r^{2}=0.71$, twice per week, week $6 ;(\boldsymbol{Q}) \mathrm{y}=-43.4(\mathrm{x})+232.3$, $r^{2}=0.35$, once per week, week $8 ;(\nabla) \mathrm{y}=-72.0(\mathrm{x})+228.1, r^{2}=0.83$, twice per week, week 8 .

*Slopes for once-a-week and twice-a-week spray treatments within the sample period were significantly different $(t$ test, $P<0.05)$

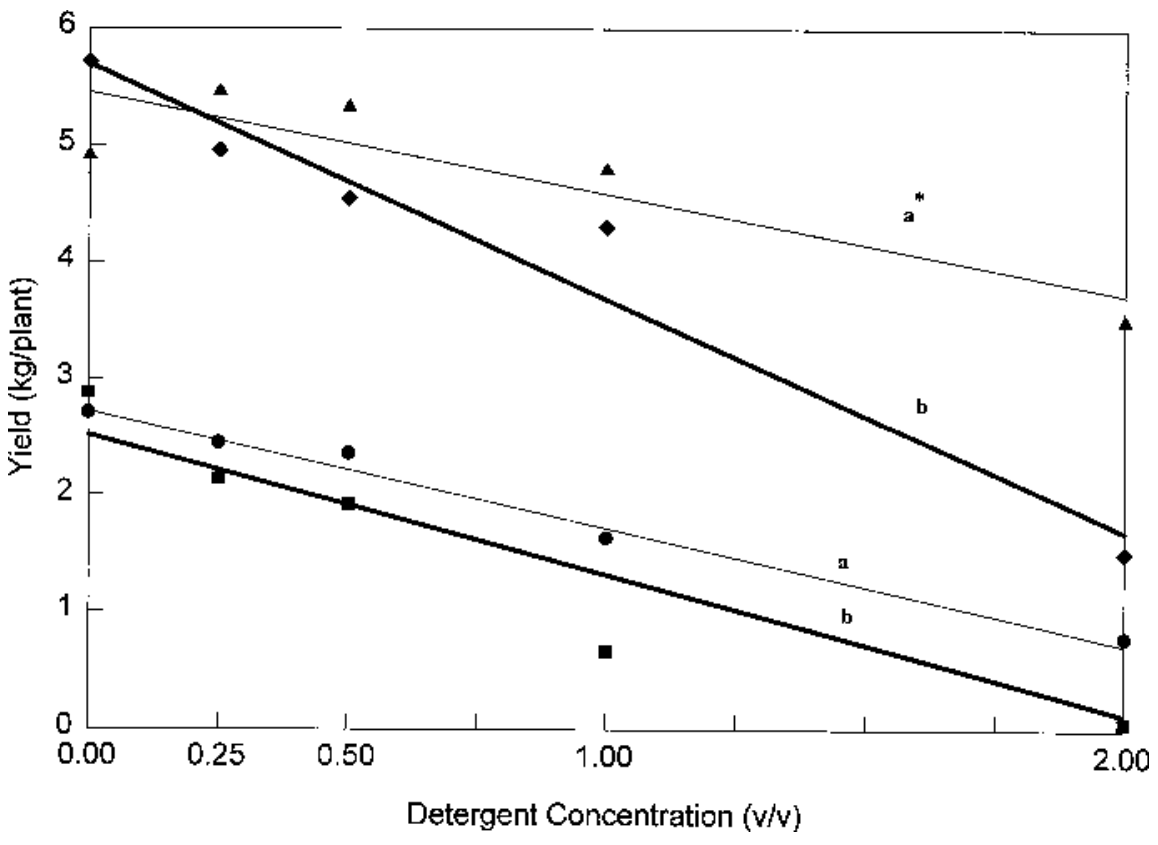

Fig. 2. The effect of New Day liquid detergent application frequency on tomato fruit yield, Fall 1991. (-) $\mathrm{y}=-1.00(\mathrm{x})+2.72, r^{2}=0.84$, once per week, first harvest; ( $) \mathrm{y}=-1.39(\mathrm{x})+2.58, r^{2}=0.78$, twice per week, first harvest; $(\boldsymbol{\Delta}) \mathrm{y}=-0.86(\mathrm{x})+5.45, r^{2}=0.39$, once per week, total harvest; $(\bullet) \mathrm{y}=-1.20(\mathrm{x})$ $+5.69, r^{2}=0.83$, twice per week, total harvest.

*Slopes for once-a-week and twice-a-week spray treatments within the sample period were significantly different $(t$ test, $P<0.05)$. 
tetramethylcyclopropanecarboxylate (fenpropathin) [2.4 emulsifiable concentrate (EC) at $0.024 \mathrm{~g}$ a.i./100 $\mathrm{ml}$ of water]-O,Sdimethyl phosphoramidothioate (methamidophos) (4 EC at $0.09 \mathrm{~g}$ a.i./100 ml water; Valent USA Corp., Walnut Creek, Calif.) tank mix in rotation with $6,7,8,9,10,10$-hexachloro1,5,5a,6,9,9a-hexahydro-6,9-methano-2,4,3benzodioxathiepin-3-oxide (endosulfan) (3 EC at $0.06 \mathrm{~g}$ a.i./100 ml; FMC Corp., Middleport, N.Y.) treatment was included as a comparison with detergent treatments for phytotoxic effects on plant growth. Fruit were harvested on 21 Dec. 1992 and 4 Jan. 1993.

\section{Results and Discussion}

Insecticidal bioassay. Although New Day contained about half the active ingredient of M-Pede insecticidal soap, it was twice as toxic to young whitefly nymphs. The concentration of New Day necessary to kill $50 \%$ of the treated population $\left(\mathrm{LC}_{50}\right)$ was $51 \%$ less than the $\mathrm{LC}_{50}$ value for M-Pede insecticidal soap (Table 1). LC $_{50}$ values differed significantly at $>95 \%$ probability, as indicated by the lack of overlap in confidence limits. The $\mathrm{LC}_{90}$ value for New Day was $62 \%$ of the value for MPede, further demonstrating the greater toxicity of New Day. These results indicated that New Day could be used at slightly more than half the labeled rate of M-Pede with the same effect on young nymphs, the lifestage most susceptible to this product (Liu and Stansly, 1995).

Field rate screening (Summer 1991). Tomato seedlings sprayed with concentrations of Tide liquid detergent at $\geq 1 \%$ were severely injured. Concentrations of $4 \%$ and $8 \%$ detergent killed $>80 \%$ of plants after the first application. Only plants sprayed with $1 \%$ detergent survived all six spray applications. Final plant dry weights were not analyzed due to excessive plant loss but were ranked as follows: control $>1 \%>2 \%>4 \%, 8 \%$ detergent $(6.38$ $\mathrm{g} /$ plant $>1.78 \mathrm{~g}>0.64 \mathrm{~g}>0,0$, respectively). Temperatures were relatively high during the test and averaged $32.8 \mathrm{C}$ at application (range 30 to $35 \mathrm{C}$ ). Excessive heat and humidity likely contributed to the high levels of phytotoxicity. These data indicated that, under conditions of this test, the detergent concentration needed to be $<1 \%$ to reduce phytotoxicity.

Field application (Fall 1991). Based on screening study results, New Day liquid detergent was used at $0 \%, 0.25 \%, 0.5 \%, 1.0 \%$, and $2.0 \%$ in Fall 1991. Reductions in tomato plant dry weight at these rates first were detected 4 weeks after planting (Fig. 1). A significant negative linear weight reduction $(P \leq 0.05)$ with increasing concentration was evident at this time and became more pronounced in weeks 6 and 8 . Greater reduction of dry matter accumulation with more-frequent spray application (once vs. twice a week) was first detected at week 6 . Visible signs of phytotoxicity were evident as marginal leaf necrosis on plants sprayed with $\geq 0.5 \%$ detergent.

At first harvest, fruit yield decreased with an increase in detergent concentration $(P \leq$ $0.05)$, with significantly greater yield losses occurring on plants sprayed twice a week (Fig. 2). Detergent at $1 \%$ applied twice a week reduced yield $53.9 \%$ compared to the control, whereas $0.25 \%$ detergent applied at the same frequency reduced yield only $10 \%$.

First-harvest yield reduction trends due to detergent rate and frequency tended to reverse in subsequent harvests (data not shown). This appeared to be a compensatory response to delayed maturity. That is, fruit were present at first harvest, but simply had not sized due to reduced growth caused by phytotoxicity.

Second-harvest yields were reduced only with detergent applications twice a week (data not shown). Yield was not affected by rate or frequency at third harvest (data not shown). Harvest totals, however, showed that increasing detergent concentration decreased yield; yield losses were greater when detergents were applied twice weekly (Fig. 2).

Yield loss could be attributed, at least partially, to a nonsoap-detergent-induced reduction in fruit weight when compared to the control (Fig. 3). At first harvest and in the combined harvest, fruit weight declined steadily $(P \leq 0.05)$ with increasing detergent concentration. No effect of detergent concentration on fruit weight was detected at the second or third harvest (data not shown). Significant differences in fruit weight attributable to frequency of detergent application were not detectable at any harvest.

Spring 1992. In this study, detergent at $0.25 \%$ or $0.5 \%$ did not consistently affect tomato plant biomass or fruit yield. However, a significant reduction in plant dry-matter accumulation at 8 weeks was evident when spray frequency of application was twice weekly compared to once weekly with New Day (111 $\mathrm{g} /$ plant vs. $141 \mathrm{~g} / \mathrm{plant} ; P \leq 0.01)$. This trend was consistent with observations made in the Fall 1991 study.

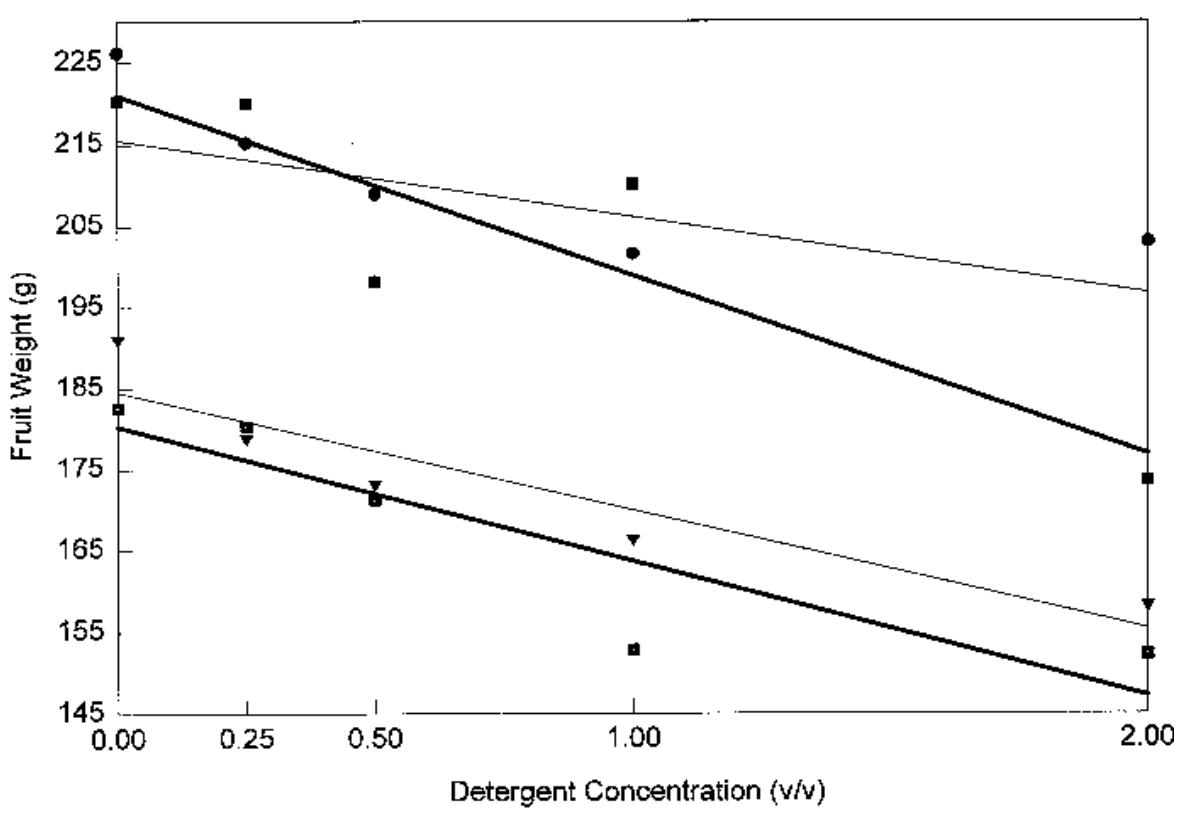

Fig. 3. The effect of New Day liquid detergent application frequency on individual 'Sunny' tomato fruit weight, Fall 1991. (O) y $=-9.4(\mathrm{x})+215.5, r^{2}=0.23$, once per week, first harvest; ( $\left.\mathbf{\square}\right) \mathrm{y}=-22.1(\mathrm{x})+$ 221.0, $r^{2}=0.43$, twice per week, first harvest; $(\boldsymbol{\nabla}) \mathrm{y}=-14.6(\mathrm{x})+184.6, r^{2}=0.54$, once per week, total harvest; $(\boldsymbol{0}) \mathrm{y}=-16.6(\mathrm{x})+180.3, r^{2}=0.67$, twice per week, total harvest. 
egy helped minimize the effect of the sprays. Where the application of detergent was delayed for 2 weeks, phytoxicity during early plant growth was reduced, and resultant tomato yields were similar to those for plants sprayed with water alone. Rainy weather also minimized phytotoxicity. No determination of insecticidal efficacy under rain events was assessed; therefore, this factor may need to be researched for SLWF control.

Yield loss from detergent-induced phytotoxicity was most pronounced at first harvest, which is generally the harvest of greatest eco-

Table 2. Effect of Tide liquid concentration on 'Sunny' tomato red fruit yield at first harvest, Fall 1992.

\begin{tabular}{lcc}
\hline \hline & \multicolumn{2}{c}{ Tomato yield (kg/plant) } \\
\cline { 2 - 3 } Treatment & Extra large & Total \\
\hline Control (water) & 2.21 & 2.38 \\
Tide liquid $(0.25 \%)$ & 0.58 & 0.66 \\
Tide liquid $(1.0 \%)$ & 1.04 & 1.15 \\
Fenpropathin/ & & \\
$\quad$ methamidophos + & & \\
$\quad$ endosulfan & 0.81 & 1.02 \\
$\mathrm{LSD}_{0.05}$ & 0.90 & 0.89 \\
\hline
\end{tabular}

nomic return. The benefit of economical whitefly suppression may outweigh the yield loss expected at first harvest when using detergents. Also, detergent delays maturity, regardless of concentration, frequency, or time of application.

We believe the $1 \%$ solution recommended by Yepsen (1984) and used by Butler et al. (1993) for the control of soft-bodied insects is inappropriate for high-pressure hydraulic commercial application in tomatoes. Based on our findings, growers should delay detergent spraying for 2 weeks (or longer) after transplanting, and then use $0.25 \%$ to $0.5 \%(\mathrm{v} / \mathrm{v})$ at a frequency of one spray per week. If whitefly infestations increase to economically harmful levels during the 2- to 3-week establishment period, more effective insecticides may be necessary.

\section{Literature Cited}

Butler, G.D. and T.J. Henneberry. 1990. Pest control on vegetables and cotton with household cooking oils and liquid detergents. Southwest Entomol. 15:123-131.

Butler, G.D., T.J. Henneberry, P.A. Stansly, and D.J. Schuster. 1993. Effect of selected soaps, oils and detergents on the sweetpotato whitefly. Fla. Entomol. 76:161-167.

Hawkins, W. 1994. Recommendations forwarded to secretary of agriculture. Fla. Tomato Rev. 25(2):1.

Kirk, O. 1983. Surfactants and detersive systems, p. 332-432. In: J. Kroschwitz (ed.). Encyclopedia of chemical technology. vol. 22. Wiley, New York.

Liu, T.X. and P.A. Stansly. 1995. Toxicity of biorational insecticides to Bemisia tabaci (Homoptera: Aleyrodidae) on tomato leaves. J. Econ. Entomol. 88:564-568.

Puritch, G.S. 1975. The toxic effect of fatty acids and their salts on the balsam wooly aphidAdelges piceae (Ratz). Can. J. For. Res. 5:515-522.

SAS Institute. 1988. SAS/STAT user's guide. SAS Inst., Cary, N.C.

Schuster, D.J., T.F. Mueller, J.B. Kring, and J.F. Price. 1990. Relationship of the sweetpotato whitefly to a new tomato fruit disorder in Florida. HortScience 25:1618-1620.

Stansly, P.A. and T.X. Liu. 1994. Activity of some biorational insecticides on silverleaf whitefly. Proc. Fla. Hort. Soc. 107:167-171.

Vavrina, C.S. 1992. Are detergent sprays toxic to plants? Amer. Veg. Grower 48(4):41-43.

Yepsen, R.G. 1984. Soap. The encyclopedia of natural insect \& disease control. Rodale Press, Emmaus, $\mathrm{Pa}$. 